機会に報告する。

擱筆するに当り御䝽篤なる御指導と御校閱を賜りたる 岡田敉授並に種る御敉示を賜りたる三村助敉授に対し梁 謝の意を表する。

\section{(本研究は交部省科学研究費によるものである。)}

\section{文 献}

1) Bardeleben's Handbuch der Anatomie des Menschen. Bd. I Abt. 1(1896). -2) Brash, J. C.: The growth of the alveolar bone and its relation to movements of the teeth, including eruption. Intern, Journ. of Orthod. 14, 196, 283, 398, 487, (1928). -3) Charles, S. W.; a) On the growth of bones. Brit. Dent. J. 47, 47(1826). b) The madder method and the growth of the mandible. Brit. Dent. J. 48, 15(1927)。一4) 福并 >定: 家鬼長骨発育に就 ての実驗的研究. 成医会誌, 51，520，(昭 7)。-5) Gross, H. : a) Experimentelle Untersuchungen zur Histologie des wachsenden Kieferknochens. Kritik und Anwendung der Vitalfärbung mit Alizarin. Ausbau und Auswertung für die mikroskopische Untersuchung. Vjschr. f. Zihnheilk., 50, 48(1934). b)「アリザリン」生体染色法による顎骨成長の㙷微鏡 的研究. 口病誌, 9,339 , (昭 10). 一6) 黑岩賢三： 骨外科に関寸る 1，2の動物実驗. 日外科会誌，19, 945, (大 7). -7) Mimura, T.: Beitrïge zur experimentellen Bleivergiftung. II. Mitteilung des Bleies in den Knochen und den Zahngeweben sowie seine Wirkung auf dieselben. Jap. J. of med. Sci. IV Pharmacol., 8, 7* (1935). -8) Möllendorff's Handbuch der mikroskopischen Anatomie des Menschen. Bd. II Tl. 2(1930). -9) 長尾優：家 鬼臼歯並に其の支持組織学的構造. 口病誌，2,63(昭 3). -10）小川美松！骨移植に関する:実驗的研究。
日外科会誌. 24，161，(大 12). 一-11) 岡田正弘, 三 ・村二：a）鉛塩による骨及び 歯牙組織新生化灰部位の 生体染色法. 口病誌, 11, 365 (昭 12) b) Zur Phys iologie und Pharmakologie der Hâttgewebe. I. Mitteilung: Eine Vitalf:irbungsmethode mit Bleisalzen uud ihre Anwendung bei den Untersuchungen iuber die rhythmische Streifenbildung der harten Zahngewebe. Jap. J. of med. Sci. IV Pharmacol., 11, $116^{*}(1938)$ c) Zur Physiolologie und Pharmakologie der Hartgewebe. IV. Mitteilung: Tagesrhythmus in der Knochenlamellenbildung. Jap. J. of med. Sci. IV Pharmacol., 13, 95*(1940). -12) a) 廖春木家鬼の顎発育に関する研究. 口病誌，15, 435 (昭 16)，470(昭 17)，17，427，(昭 18) b) 家蚛 の橫口蓋攽譬と顎発育との関係. 口病誌，15，436(昭 16） c) 醋酸鉛生体染色法による骨組織の 発育に関 する研究. 'ㅁ病誌, 17, 425(昭 18) d) 硬組織の生 理及び藥理(11 報) 醋酸鉛生体染色法による骨組織 形成速度の研究。日藥会誌， 40,90 (昭 10)。-13) Proell, F. W. : Beitrïge zur vitalen Knochenfärbung. Zeitschr. f. Zellforschung. 3, 461(1926). 14) Proell, F.und Wyrwoll, R.: Experimentelle Untersuchung über das Wachstum des Unterkiefers und der Zähne. Dtsh. Zahn- Mund-, u. Kieferheilk., 1, 81(1934). 一-15) 声野䍵次：生体染色之研 究. 2版, 507(昭 4). -16) Wegner, G: Ueber das normale und pathologische Wachstum der Röhrenknochen. Virchow's Arcoiv., 61, 44(1874). -17) Wolff, J. : a) Ueber Knochenwachstum. Berl. Klin. Wochenschr. (1868). b) Markierversuch an Lscheitel-, Strin-, und Nasenbein des Kaninchens. Virchow's Archiv. 101, 5725, (1886) c) Ueber das Wachstum des Unterkiefers. Virchow's Archiv., 114, 493(1888).

\title{
Esperin 添加培養に依る非抗酸性結核菌の
}

\section{病 原 性に就て}

\author{
橫浜市立医医科大学細菌学教授室(主任 東風教授) \\ 武井盈 \\ (Takei-Mituru)
}

\section{1. 緒 言}

著者は既に結核菌を新抗菌性物質Esperin を浗 加して培養する䀛合に， $\mathrm{S}$ 型集落を形成して非抗
酸性顆粒乃至桿菌を認めることを報告した。純粹 狀態に近い非抗酸性結核菌を認めた場合思考され ることは先す病原性の滅弱であつて, 若し非抗酸 
結核菌が結核菌の死を意味するものでなければ当 然本菌に B.C.G. 類似作用なき否やが檢討さ れるべきである。

この非抗酸性結核菌の病原性は，その非抗酸性 結核菌そのものが多数の疑点を包含する現今にお いて極めて多くの問題を提出するものである。師 占非抗酸性結核菌中に雜菌㥞発育を営屯。の迄包 含せしめるならば，その病原性は恐らく結論を得 るに困難であると思われる。

吾々の論する非抗酸性結核菌は飽く迄雜菌柡発 育を営ます明かに結核菌であることが証明される もののみである。これに類するものとして現今迄 報告されたものは Saponin，添加培養に依る有馬 等の非㧒酸性結核菌, Convallamarin, Digitonin, Digitalin 添加培養に依る長谷川並びに東風等の 非抗酸性結核菌が代表的なものと思われる。然し これ等の非抭酸性絬核菌は純粹狀態において求め られるものなく，抗酸性菌中に比較的多数の非抗 酸性桿菌か漰現するに過ぎす，非抗酸性結核菌そ のものの病原性を檢することは不可能である。随 つて現今迄において，非抗酸性絬核菌の病原性を 檢することは比較的な事項に属するるのであつ て, 絕対的なものではない。非抗酸性絬核菌が純 粹狀態に得られたとする報告の殆んど総てい雜菌 样発育を営むもので結核菌であると制定すること 困難なものが多い。著者は Esperin を涯加培養す ることに依つて殆んど純粹に近い非抗酸性顆粒乃 至桿菌の培養を得たか; 㮀めて少数の抗酸性桿菌 の混在はさけられなかつた。

著者は此の培養菌を用いて海猽に対する感染試 驗を行つた結果，之の病原性は極めて減弱するこ とを認めたっこの非抗酸性結核菌の生死の問題は 確実なる方法で更に追求さるべきであるが，若し 本菌が生存して居るならば感染免疫原として價值 を有するものと考えられる。

\section{2. 文 献}

礁実に結核菌より由来すると考えられる非抗酸 性結核菌郎ち䆶菌樣発育を呈しないもののみに就 ての病原性を文献的に檢討すると，志賀は結核菌 に対して著明な発育を阻止する物質, 郎ち Tryp- aflavin, Neutralrot, Erythrosin 等を多量に加え た「グリセリンブイョン」中において発㕕する樣に 馿化さした結核菌は，大部分非抗酸性となり，海 猽の靜脈內に $2 \mathrm{mg}$, 腹腔內に $1 \mathrm{mg}$ 接種しても殆 んど毒性を現わさなかつたと述へて居り，有馬， 青山, 大繩營は Sapindus Mucurosii japonica よりとつ方 Sapnnin を培地內に添加して人型結 核菌を培養し，その抗酸性を減弱せしめを結核菌 は毒力次第に減弱し，家鬼靜脈內に $1-5 \mathrm{mg}$ を注 射しても数週間の注過では何等の病変をも起さな い。しかし 10-100 mg では肺に小結節を作るが 他の臟器には何等の変化をも起さず， 3 週間後に

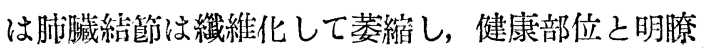
に区别することが出来た。海㩧皮下に $10 \mathrm{mg}$ 接種 した埸合には接種局所は乾酪性基部を有する潰瘍 を作り所属淋巴腺の肥大が認められたが，海猽の 全身感染には $100 \mathrm{mg}$ 以上の菌を要主ると述へて 居る。飯島は Saponin 添㞦培地上に約 50 代継 培養を続け，抗酸性並びに抗アルコール性の減弱 した結核菌は海猽に対して病原性が認められると 報告して居る。

東風は Convallamarin, Digitonin 添加培養に 依りて得られた非抗酸性結核菌を海猽皮下に接種 した絬果, 実驗群, 対照群共に 3 週間後には同樣に 「ツベルクリン」反應陽轉し，解剖所見においても 対照と劣らぬ病原性が認められたと述へて居る。

\section{3. 実驗方法}

人型結核菌 $\mathrm{H}_{2}$ 株を Esperin 10 万倍濃度に含 有する「グリ七リン」寒天上に $37^{\circ} \mathrm{C} に$ 約 3 カ月間 培養して得られたS型集落の結核菌 (Esperin 菌 と称す)を以て生理的食塩水菌浮游液を作製し, こ の菌浮游液の 1 部をとり染色檢鏡し, 原型の抗酸 性結核菌は殆んど存在しないことを確がたもの を海猽腹部皮下に接種した。対照としては Esperin を含有しない「グリ七リン」寒天上に同樣にし て約 3 力月培養を続行した人型結核菌 $\mathrm{H}_{2}$ 株を, 瑪瑙乳鉢にて充分に磨碎して製した生理的食塩水 菌浮游液を同じく健康海猽腹部皮下に接種した。 実驗動物は体重 $300 \mathrm{~g}$ 內外の健康海猽を使用し, 予め「ツベルクリン」反應を実施し碓実に陰性なる 
ことを碓認したすのを 5 匹宛 2 群に分ち実驗した 郎古籍 1 群は Esperin 菌 $10 \mathrm{mg}$ 宛, 第 2 群に於 ては対照絬核菌 $0.1 \mathrm{mg}$ 宛をこれ等海猽の腹部中 央皮下に接種し，飼有 100 日後に「エーテル」腃醉 责以て屠殺後, 臬ちに解剖、各臟器に於ける病変 を檢柰した。

\section{4. 実驗成績}

I 接種動物飼育中に於ける変化

A）接程部位：接程後対监群は約2週閒後にお

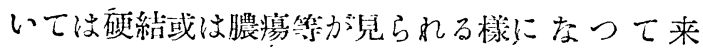
る。これ等は次䧻に大となり硬絬当軟化し化膿す るもの，或は自潰し潰瘴を形成しているもの等が 見られる栐になつて来る。その大さ程偲等は対照 群において最も著明であり，二船に䭪湯を形成し ているもの多く，拇指頭大又はそれ以トの大さを 付する硬䋨胃られるのが普通であるが実驗群に

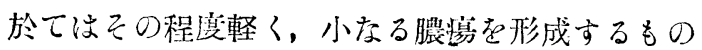
あるも大部分は殆んど变化か認められない。

B）所属淋巴腺：腹部皮下に接程後, 約 2 週後

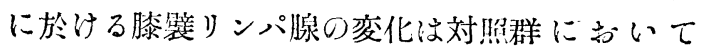
は，小豆大から大豆大の硬いリンパ脉を触知出来 るが，実驗群においては何れも著明でなかつた。 約 10 週間後においては，対照群は何れにおいて る硬い大豆大以上に腫脹した湘巴腺を触知するこ とが出来るが，実驗群敏猽のリンパ腺は大部分正 常大であり，時に稍々腫脹して店るりを認めた。

C）体重に就て：菌接種後何れの群においても 著明な変化が見られす，100日鸰育後においては 平均 $200 \mathrm{~g}$ の体重增㞦が見られたか;，実驗群対照 群の間における著明な体重の差は認められなかつ ね。

D）ツベルクリン反應：菌接種後，20日目に 「ツベルクリン」10 佔稀釈液を，海猽背部皮冈に $0.1 \mathrm{cc}$ 宛注射し， 48 時䦌後にその成績を制定した。 実驗群㕍猽においでは $0.5 \mathrm{~cm}$ 內外の発赤最も多 く自られ。軽度のもの多かつたが反應の認められ なかつををのはなかつた。

対照群においては，実驗群に比すればその程度 一般に强く，1 cm 以上の径を有する発赤の見られ るものが多かつた。しかし実驗群，対照群共に，
接種 20 日後において「ツベルクリン」反應は陽轉 したのが認められた。

\section{II 解剖所見}

菌接種後 100 日目に生存実驗動物を「エーテル」 梳醉を以て屠殺し，直ちに解剖，その臟器及びリ ンパ腺の羅患狀態を檢菜した絈果は, 表1に示す 如くである。

表 1 対照群

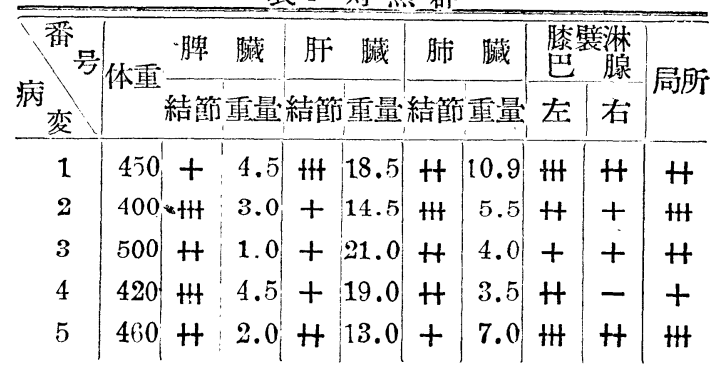

変異菌 $10 \mathrm{mg}$ 注射群

\begin{tabular}{|c|c|c|c|c|c|c|c|c|c|c|}
\hline & & 脾 & 臟 & 肝 & 臟 & 肺 & 臟 & \multicolumn{2}{|c|}{$\begin{array}{l}\text { 棪襞淋 } \\
\text { 腺 }\end{array}$} & \\
\hline & \multicolumn{7}{|c|}{ 結篩重量結篩重量結節重量 } & tr: & 右 & \\
\hline 1 & 400 & - & 0.5 & - & 10.5 & - & 3.5 & - & - & \pm \\
\hline 2 & 450 & - & 0.6 & - & 11.5 & - & 5.4 & $H$ & + & + \\
\hline 3 & 460 & - & 0.9 & - & 9.5 & - & 4.3 & - & - & - \\
\hline 4 & 500 & - & 0.8 & - & 110 & - & 5.0 & + & - & - \\
\hline 5 & 480 & - & 1.0 & - & 10.2 & - & 4.0 & \pm & - & - \\
\hline
\end{tabular}

これ等実驗群のリンパ腺組織及び接種局所の組 織病像においては，膠質線維及び壞死巢，特に乾 酪化を認めること出来ず，なおその傾向も殆んど 認められず, 対憵群に比較するに, 実驗群において は何れも病理組織学的にも感染程度微弱にして, 良性の病像を呈しでいることが認められる。

脾臟, 肝臓, 脯臟等の各臟器における結節形成 又は肥大等の変化は，対照群においては著明に認 めることが出来たが，実驗群においては結節形成 や認めることが壮来ず，大さにおいても殆んど正 常形態のものであり，重量においても対照群の如 く增加しているものを認河ることがなかつた。

以上の如く対照群に衿いては何れの臟器におい ても典型的結核病変を認めることが出来たか，実 驗群においては小数例においてのみリンパ腺並び 


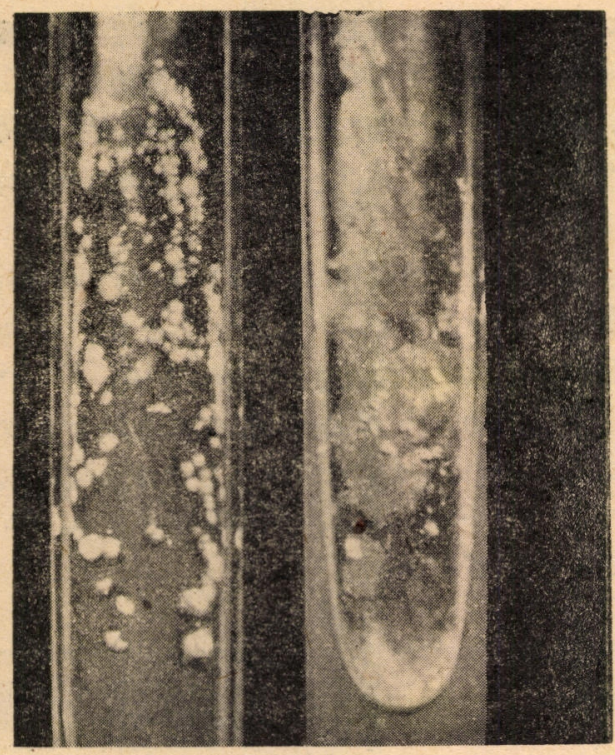

附図 Esperin 源加培養一依る非抗酸性結核菌の $\mathrm{S}$ 型集落。(右刘照)

(横浜医学, 第 1 卷 $2-3$ 号, 81 頁参照)

に局所に，良性の結核病変が見られたのみであつ た。

\section{III 細菌学的檢查所㫛}

肉眼的に変化の認められる摘出リンパ腺を乳鉢 にて充分に磨碎し，「アンチフォルミン法を以て 集菌し，Ziehl-Neeilsen 染色法を施行し，檢鏡す るに，対照群においては抗酸性桿菌を多数に認め ること出来たが，実驗群においては主として軽度 の彎曲を示す細長い緎細な抗酸性桿菌が認められ
るが, 菌数比較的少く， 一視野に 2-4 個の 菌か 認められる程度であつた。なお接種菌液に認めら れる如き非抗酸性の顆粒乃至桿菌は見ることが出 来なかつた。

この集菌したものね，「岡一片倉」培地並びに Coper 培地に塗沫, $37^{\circ} \mathrm{C}$ に培養すると，約 2 -3 週間にして結核菌集落と全然異らない抗酸性桿菌 の発育して来るのが認められるが，その集落数は 対照培養に比して極もて少なく，1 試驗管に25 個に過ぎない。

\section{5. 総括並びに結論}

抗酸性菌抗酸性菌に対して抗菌作用を有する Esperin を添扠培养することに低り，殆んど檢鏡 的に非抗酸性顆粒乃至桿菌よりなる $\mathrm{S}$ 型集落を生 ずるが、本菌を海樭皮下に接種した場合に，その 瘦原性極ひて弱々, $10 \mathrm{mg}$ 接程に丸゙いてはリンパ 腺の腫脹並びに接種局所に膿湸を形成するものが 見られたが，他の內臟その他において結核㾟変を 認めることは出来なかつた。

終りに臨み学校長高木博士並びに長欲川東大㸚授に敬 意を表し，御指導を晹つた東風教授に深く感謝の意を捧 げる。

\section{文 街}

1) 武井: 橫浜医学, 1 卷, $2-3$ 号.

2) 志賀 : Kitasato's Archives of Exp. Med. 1, 1917.

3) 有馬, 青山, 大繩 : 結核, 1 夋, 1-5号.

4) 飯島: 東北医学雜誌 17 怣, 4 号.

5) 東風：第 14 回，联合微生物学会総合.

\section{Pf eiffer 氏血液加第 2 塩化銅溶液結晶像}

の臨床的應用について

東京医科崡科大学內科㸚公 (主任 佐及教授)

閣

田

進

(Okada-Susumu)

\section{緒 霉}

1938 年 Pfeiffer は塩化銅溶液に少量の有機物
を加え，一定條件のるとに結晶形成を起さすと き，結核の場合には実驗動物で特長のある交叉型 